\title{
New categories for the climatic division of snowy areas in Japan
}

\author{
MAsaAki Ishizaka \\ Toyama Science Museum, 1-8-31.Nishi-Nakano, Toyama 939, Japan
}

\begin{abstract}
New categories for the climatic division of snowy areas according to their snow-cover character in mid-winter are proposed. They are a wet-snow region, a dry-snow region, an intermediate snow region and a depth-hoar region. The wet-snow region is defined as the region in which every layer of deposited snow is wet due to percolation of snowmelt water throughout the winter. In contrast, areas in which the snow cover is dry, at least in the coldest period of the winter season, are classified into two categories, that is the dry-snow region and the depth-hoar region. In the latter region, the small snow depth and low air temperature induce development of depth hoar. The intermediate snow region was introduced to indicate an intermediate character between the dry-snow and wet-snow regions. From the climatic dataset calculated by the Japanese Meteorological Agency and from snow surveys, it has been found that in snowy areas, which have a climatic monthly mean temperature in January $\left(T_{\mathrm{jan}}\right)$ higher than $0.3^{\circ} \mathrm{C}$, snow would be expected to be wet throughout the winter and, in areas that have $T_{\text {jan }}$ lower than $-1.1^{\circ} \mathrm{C}$, to be dry at least in the coldest period. Snow covers, where $T_{\text {jan }}$ is between these two values, are expected to have intermediate characters. Therefore, these temperatures are supposed to be critical values among the wet, dry and intermediate snow regions. The criterion that separates the depth-hoar region from the dry-snow areas was found to be given by a climatic mean temperature gradient. This value lies between $10^{\circ}$ and $12^{\circ} \mathrm{Cm}$, which is derived by dividing the absolute value of the average of the climatic monthly mean air temperature, which is always below $0^{\circ} \mathrm{C}$, by the average of the monthly maximum snow depth during January and February.
\end{abstract}

\section{INTRODUGTION}

The Japanese Islands are located on the east side of the Eurasian continent. In winter, the northwesterly monsoon carries heavy snowfalls to areas facing the Sea of Japan. These areas have a wide range in latitude from $35^{\circ} \mathrm{N}$ to $45^{\circ} \mathrm{N}$, and belong to different climatic zones. Therefore, not only the amount of snow but also the quality of the snow cover varies with latitude. Nakamura (1979) has pointed out this fact, showing the differences in the layer structures of the snow covers observed simultaneously at five different places in Japan around the end of January. Many other snow surveys and pit-wall observations at fixed points have indicated that the characteristics of a snow cover are strongly dependent on the meteorological conditions in winter.

Some studies have been done to reveal relationships between regional snow characteristics and meteorological conditions. Akitaya and Endo $(1980,1982)$ have clarified the meteorological conditions in which depth hoar is expected to develop on Hokkaido Island. Izumi and Akitaya (1986) have proved that this study is also applicable to snow covers on Honshu Island. Kawashima and others (1987, 1994) investigated the snow cover in plain areas facing the Sea of Japan, dividing them into 11 regions, and they also discussed the relationship between the predominant type of snow metamorphism and the meteorological conditions.

These studies succeeded in explaining the regional characteristics of the snow cover using meteorological criteria. But the meteorological conditions in winter are often anom- alous, so that conditions in the snowy areas vary from yearto-year. Therefore, it is necessary to discuss not only the meteorological but also the climatological aspects for a holistic understanding of the regional characteristics of the larger snow-covered areas.

In this work, I propose new categories related to climatic values by indicating the differences between snow-cover quantities in mid-winter. I shall also present criteria for the categories, adapting all of them to the snowy areas in Japan.

The climatic values used here are the data derived from the climatic dataset calculated by the Japanese Meteorological Agency (JMA). These are the climatic monthly mean air temperature and the climatic monthly maximum depth of snow. JMA has calculated these climatic values for every $1 \mathrm{~km}$ square area throughout Japan with multiple regression formulae that reflect the relationships between topographical conditions and climatic values. The basic climatic values consist of 30 year averages of meteorological data observed at official observation sites in Japan.

\section{DEFINITION AND METHODOLOGY}

\subsection{Definition of the categories}

The four categories introduced are the wet-snow region, the dry-snow region, the intermediate snow region and the depth-hoar region. The wet-snow region embraces snow areas where almost every layer of deposited snow is wet due to percolation of snow meltwater throughout the winter 
season. The snow cover in this region is governed by meltmetamorphism even during the coldest period of the winter season. In snowy areas, which are clearly colder than the wet-snow region, the snow cover would be expected to be dry at least during the coldest period. They are divided into two snow-type regions, namely, the depth-hoar region and the dry-snow region. The depth-hoar region is characterized by a cold climate and little snow depth. There, the temperature gradient in the snow cover is such that depth hoar is formed. In other dry snowy areas, where the depth of snow is relatively large, fine-grained dry snow is expected to develop. The intermediate snow region has a transitional character, mainly between the wet- and dry-snow regions. This category was introduced because the boundary between the wet- and dry-snow regions is not explicit.

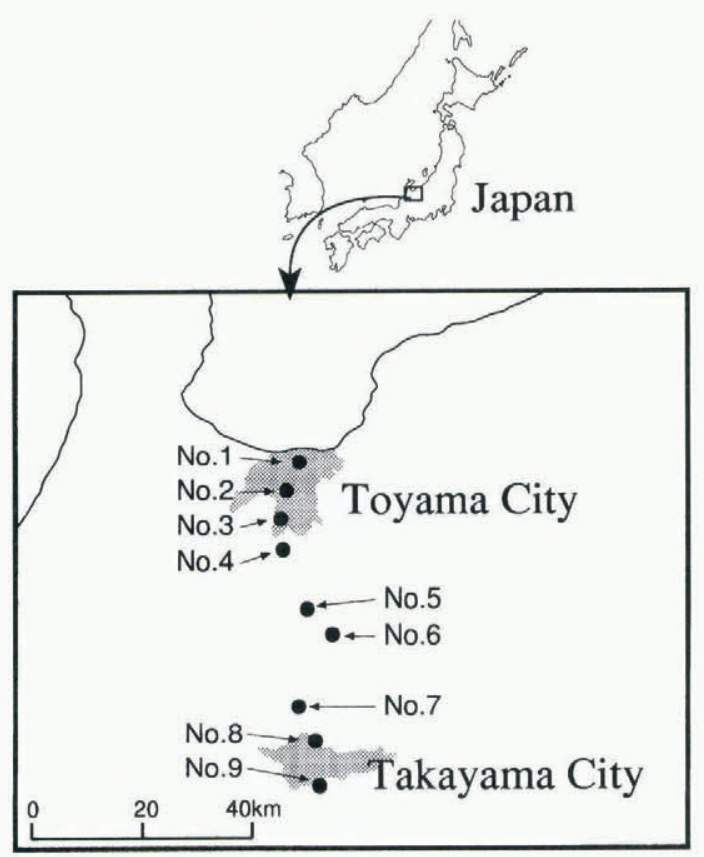

Fig. 1. Location of the snow survey sites.

\subsection{Boundary between the wet- and dry-snow region}

In order to obtain criteria between the wet- and dry-snow regions, snow surveys were carried out in mid-winter of 1983, 1985 and 1986. Observations of snow stratigraphy, snow type, snow temperature and a few mechanical properties were made using the pit-wall method at the sites shown in Figure 1. The sites are distributed from the sea coast of
Toyama City to the inland areas of Takayama City. The farther the site is from the sea coast, the colder is the winter climate, as is indicated by the climatic monthly mean temperature in January $\left(T_{\mathrm{jan}}\right)$ in Table 1 . Based on the snow surveys, the snow cover of sites No. 1 to No. 5 were completely wet. At the innermost sites, from No. 6 to No. 9, dry-snow layers with snow temperatures lower than the melting point were detected and evidence of melting was not found in the upper snow layers. From these results, it might be concluded that those regions where it is climatically colder than at site No. 6 , where $T_{\text {jan }}$ was $-1.1^{\circ} \mathrm{C}$, the snow was dry at least in the coldest period. In the warmer areas such as No. 5 , where $T_{\text {jan }}$ was $0.3^{\circ} \mathrm{C}$, the snow was wet even in mid-winter, because January is the coldest month of the winter period.

Whether snow is wet or not does not depend on the depth of the snow, for snowmelting occurred at the boundary between the atmosphere and the snow cover. Therefore, around these values, boundaries between the wet-snow region and the dry-snow region must be assumed. The areas with $T_{\text {jan }}$ between these two values might be classified as the intermediate snow region.

\subsection{Depth-hoar region}

To separate the depth-hoar region from those regions of cold climate and from the snowy areas, an empirical equation shown by Akitaya and Endo $(1980,1982)$ was used. They stated that the development of depth hoar weakens the snow cover. Therefore, depth hoar is observed to develop in snowy areas where the mean Swiss rammsonde hardness $(R)$ is smaller than $8 \mathrm{~kg}$, which was calculated from the meteorological values using Equation (1) (Akitaya and Endo, 1980, 1982):

$$
R=0.339\left(H_{1} /|T|\right)^{1.21} H_{2}^{0.21}
$$

where $|T|$ is the absolute value of the monthly mean temperature during January and February, which is always below $0^{\circ} \mathrm{C}, H_{1}$ is the monthly average snow depth of January and $\mathrm{H}_{2}$ is the snow depth at the end of February.

For adapting this empirical equation to this work, the long-term climatic values were used instead of short-term meteorological ones. Namely, $|T|$ was replaced with the climatic monthly mean air temperature, $H_{1}$ with the climatic monthly maximum depth of snow during January and February (JMA did not calculate climatic monthly mean snow depth) and $H_{2}$ with the average of the monthly maximum snow depth during February and March, instead of the depth of snow at the end of February.

Table 1. Main snow state observed by snow surveys and the climatic monthly mean air temperatures in fanuary at the observation sites estimated by the climatic grid data. The locations of the sites are shown in Figure 1

\begin{tabular}{|c|c|c|c|c|c|c|c|c|c|c|}
\hline \multicolumn{2}{|c|}{ Site no. } & 1 & 2 & 3 & 4 & 5 & 6 & 7 & 8 & 9 \\
\hline \multicolumn{2}{|c|}{$T_{\mathrm{jan}}\left(0^{\circ} \mathrm{C}\right)$} & 2.4 & 2.3 & 1.9 & 1.2 & 0.3 & -1.1 & -2.0 & -2.3 & -3.0 \\
\hline Main snow state & $\begin{array}{l}\text { 26-27 Jan } 1983 \\
\text { 31 Jan-1 Feb } 1985 \\
\text { 29-30 Jan } 1986\end{array}$ & $\begin{array}{l}\text { wet } \\
\text { wet } \\
\text { wet }\end{array}$ & $\begin{array}{l}\text { wet } \\
\text { wet } \\
\text { wet }\end{array}$ & $\begin{array}{l}\text { wet } \\
\text { wet } \\
\text { wet }\end{array}$ & $\begin{array}{l}\text { wet } \\
\text { wet } \\
\text { wet }\end{array}$ & $\begin{array}{l}\text { wet } \\
\text { wet } \\
\text { wet }\end{array}$ & $\begin{array}{l}\text { dry } \\
\text { dry } \\
\text { dry }\end{array}$ & $\begin{array}{l}\text { dry } \\
\text { dry } \\
\text { dry }\end{array}$ & $\begin{array}{c}\text { depth hoar } \\
\text { dry } \\
\text { dry }\end{array}$ & $\begin{array}{c}\text { depth hoar } \\
\text { dry } \\
\text { depth hoar }\end{array}$ \\
\hline
\end{tabular}


Table 2. Climatic division of snow-cover environments

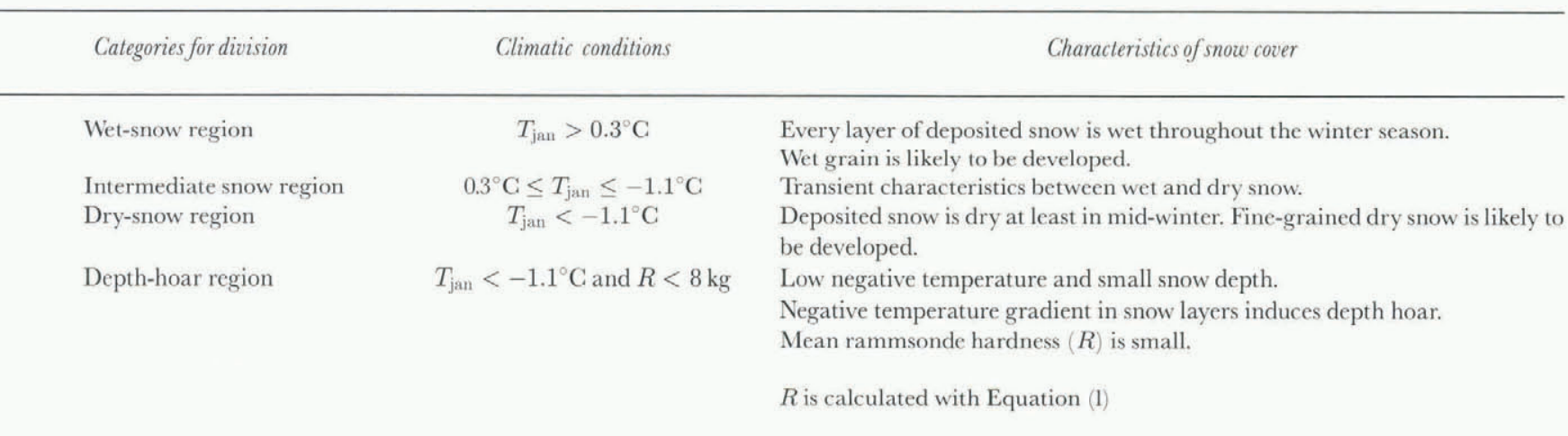

\section{RESULTS AND DISGUSSION}

\subsection{Climatic division of snowy areas in Japan}

Table 2 shows the categories introduced here, their definitions and criteria. Adapting this division to the Japanese snowy areas which have a monthly maximum snow depth more than $10 \mathrm{~cm}$ in any month during December-March, we obtained a digital cartographic map of the climatic division of snow areas in Japan (Fig. 2). Figure 2 shows that the wet-snow regions are present widely in the plains along the Sea of Japan coast at latitudes below $40^{\circ} \mathrm{N}$ and the depthhoar regions are situated mainly in the eastern and southern parts of Hokkaido Island and in a few inland areas in the central part of Japan. The many parts of the wet-snow region correspond to heavy snowfall areas. People living there generally talk about the character of the deposited snow as being "wet and heavy". That is one of typical features of Japanese snowy areas in a temperate climatic zone, where the Siberian monsoon blowing over the Sea of Japan brings large amounts of snowfall.

The map also explains well the regional variations in the initial period of wet-grain formation in the snow cover due to percolation of snow meltwater reported by Kawashima and others (1987). Comparing Figures 2 and 3, we recognize that at Toyama, Nagaoka and Asahi, which belong to the wet-snow region, the wet-grain formation has also frequently occurred in the coldest period, around the end of January or the beginning of February. On the other hand, at Sapporo and Hirosaki, in the dry-snow region, the wet-

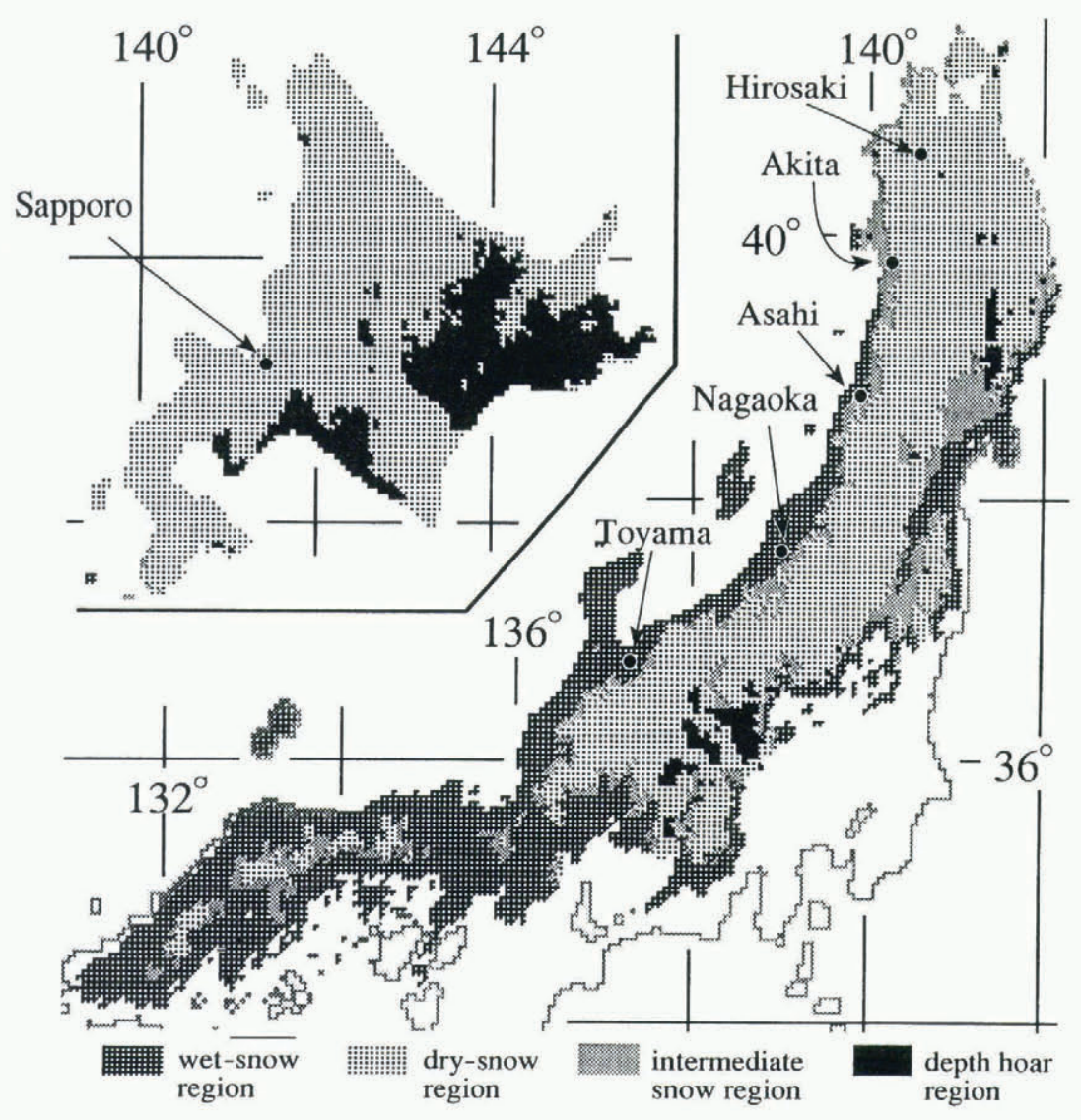

Fig. 2. The digital cartographic map of the newly calculated climatic division of snowy areas in fapan. 

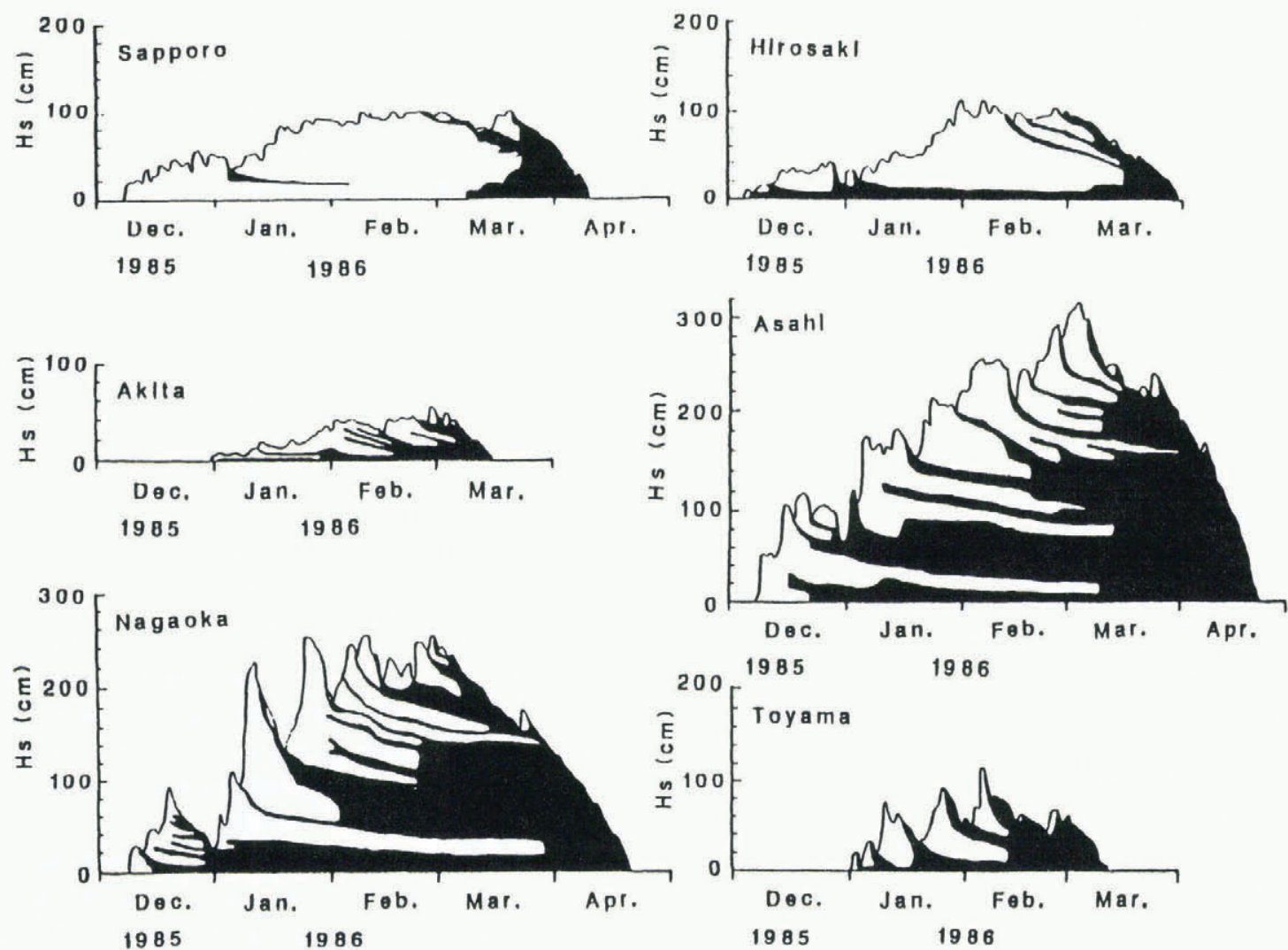

Fig. 3. Wet-grain formation in snow covers at five sites (Kawashima and others, 1987). The black parts indicate the wet-grain layers in the cross-sections of snow covers.

grain formation has not occurred in this coldest period. At Akita, in the intermediate snow region, this behavior was observed during the period between these two periods.
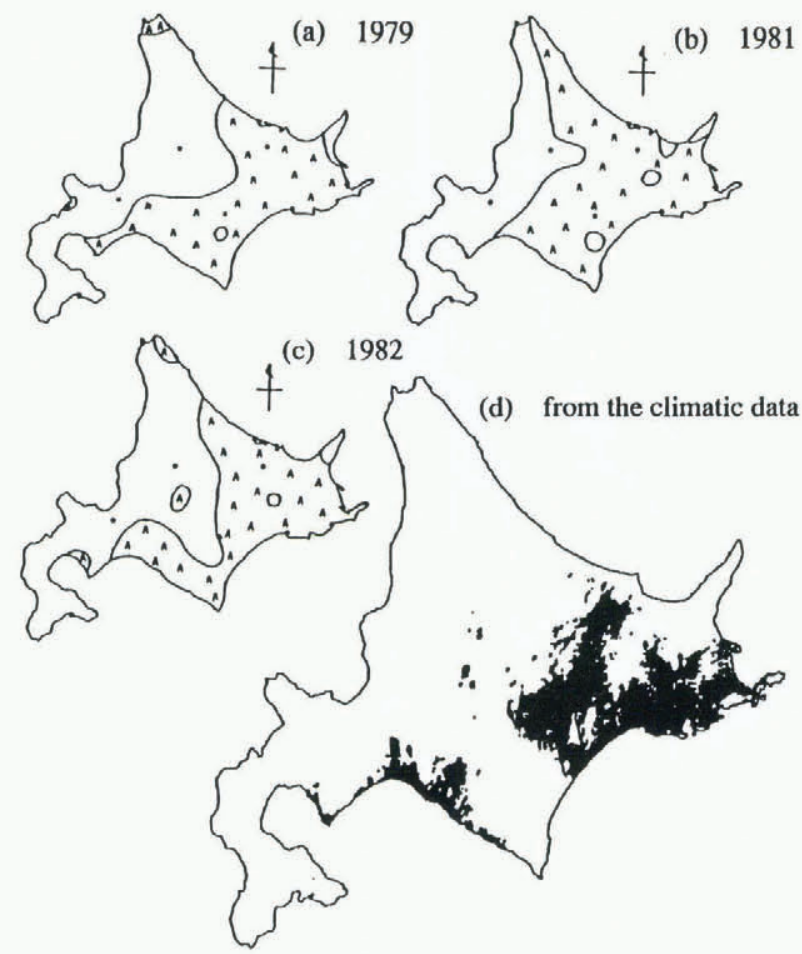

Fig. 4. Areas where depth hoar is expected to develop, as approximated by Akitaya and Endo (1982) with meteorological values of three winter seasons $(a),(b),(c)$ and those approximated by the author with the climatic grid data of $7 M A(d)$. https://doi.org/10.3189/1998AoG26-1-131-137 Published online by Cambridge University Press
Figure 4 shows the predominant depth-hoar snowy areas on Hokkaido Island, derived from both the estimation by Akitaya and Endo (1982) and my approximation. Although my result is substantially coincidental with their estimate, the "depth-hoar" areas are smaller. This lower estimation, in areal coverage, might be due to overestimation of $R$ in Equation (1), because the monthly maximum snow depth here was used instead of the monthly average values. I should like to discuss this further in section 3.3.

\subsection{Relationship between average air temperature and snow depth}

Figure 5 shows the relationship between the average of the climatic monthly maximum snow depth and the monthly mean air temperature during January and February, according to snow-type regions.

In the wet-snow region, the upper limit of the snow depth decreases as the air temperature increases. Almost all of the data from the wet-snow region exist below a line drawn from $6^{\circ}$ on the abscissa to $2 \mathrm{~m}$ on the ordinate (Fig. $5 a)$. This indicates that the accumulation of snow is controlled by the melting process in the warmer snowy areas. This tendency could also be confirmed by the observed data from official observation sites in Japan.

Comparing (c) with (d) (in Fig. 5), we discover that data from the dry-snow region and the depth-hoar region are separately distributed on two opposite parts of the graph. To obtain the best-fit curve dividing the two groups, the data from the boundary regions, in which the calculated rammsonde hardness $R$ values were between 7 and $9 \mathrm{~kg}$, were 
(a) Data from the wet snow region

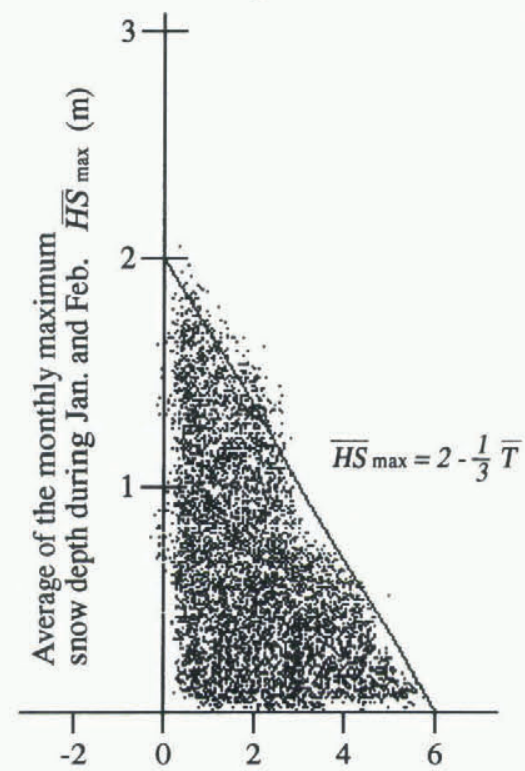

Average of the monthly average temperature during Jan. and Feb. $\bar{T}\left({ }^{\circ} \mathrm{C}\right)$

(b) Data from the intermediate snow region

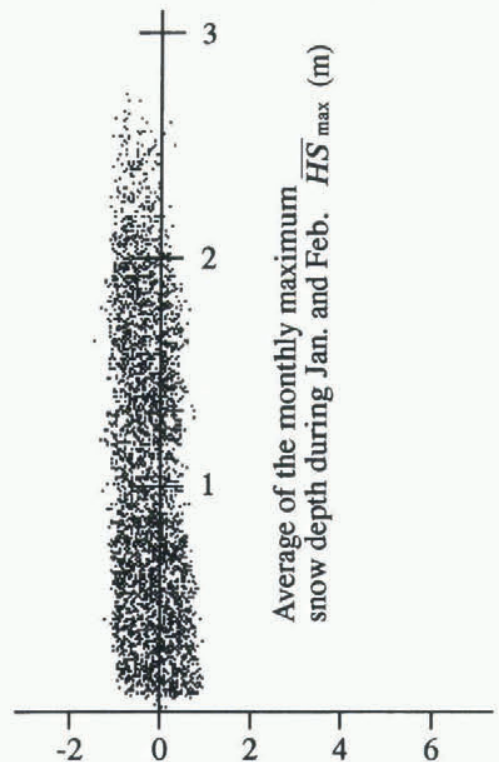

Average of the monthly average temperature during Jan. and Feb. $\bar{T}\left({ }^{\circ} \mathrm{C}\right)$ (c) Data from the dry snow region

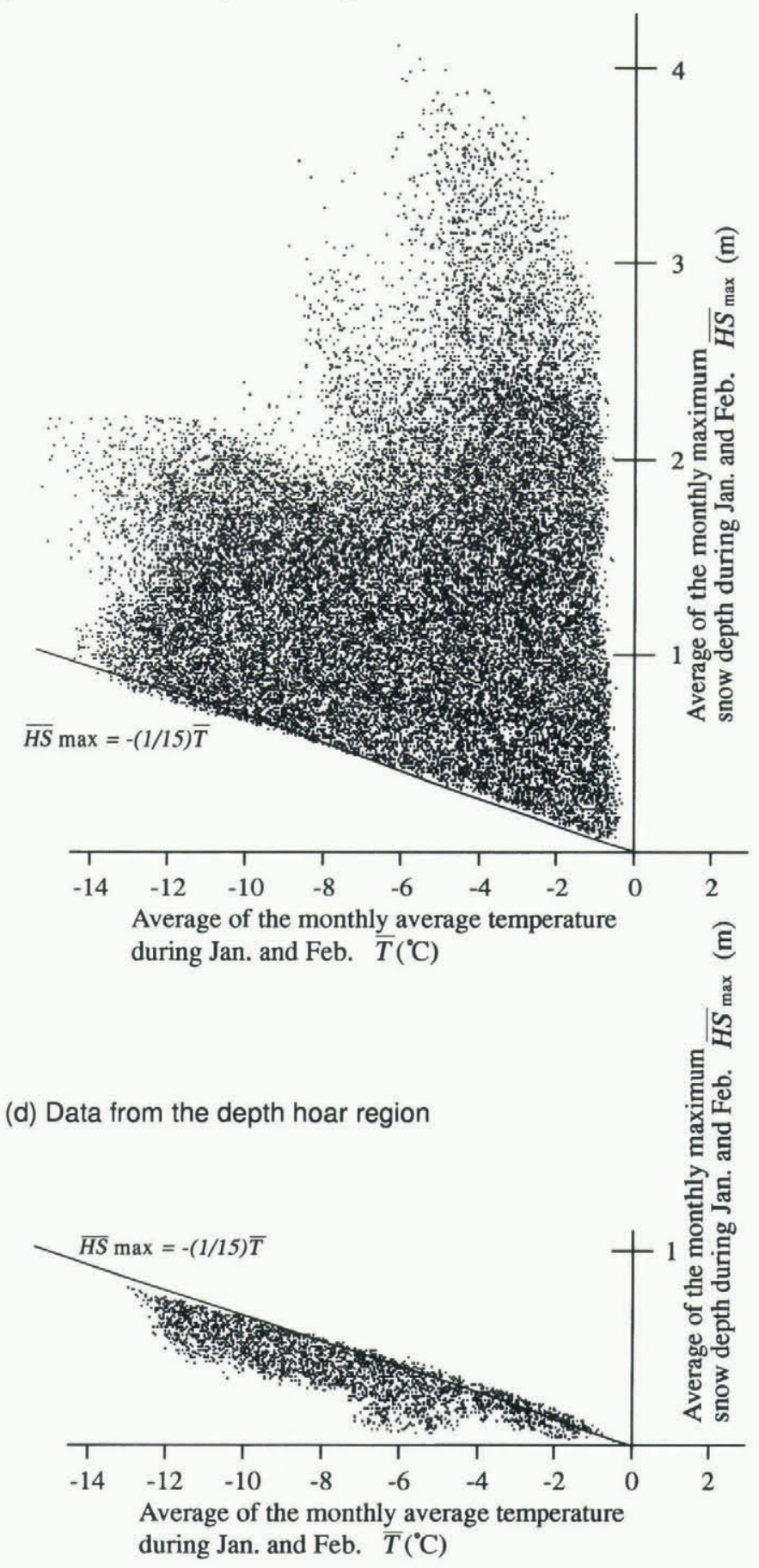

Fig. 5. The relationship between the average monthly maximum snow depth during January and February, $\overline{H S}_{\max }$ and the monthly mean air temperature, $\bar{T}$. The line drawn in $(c)$ and $(d)$ represents a climatic mean temperature gradient of $15^{\circ} \mathrm{Cm}^{-1}$.

chosen (Fig. 6). The equation expressing the curve has been approximated as follows:

$$
\overline{H S}_{\max }=0.094|T|^{0.84}
$$

where $\overline{H S}_{\max }(\mathrm{m})$ is the average of the monthly maximum snow depth during January and February and $\bar{T}\left({ }^{\circ} \mathrm{C}\right)$ is the monthly mean air temperature during the same period, which is always negative. The absolute value of the slope of the curve corresponds to the inverse of the temperature gradient of the boundary data. I call this value "climatic mean temperature gradient". So we could find that the climatic mean-temperature gradient of the boundary data at lower temperatures were larger than those at higher temperatures. This tendency is reasonable, because in cold snowy areas ground temperatures are expected to be below $0^{\circ} \mathrm{C}$, so that a mean temperature gradient estimated from air temperature and snow depth would be smaller than the actual ones.

Simplifying, a linear expression of the boundary data was obtained by

$$
\overline{H S}_{\max }=0.07|\bar{T}|
$$

where the variables are the same as in Equation (2). This approximated linear expression corresponds to the line, 


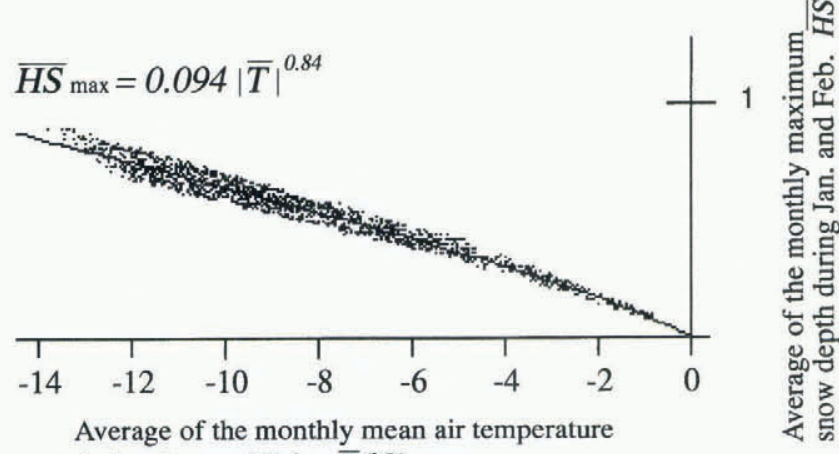

during Jan. and Feb. $\bar{T}\left({ }^{\circ} \mathrm{C}\right)$

Fig. 6. $\overline{H S}_{\max }-\bar{T}$ relationship for the boundary points where approximated rammsonde hardness $R$ ( $c f$. Table 2) satisfies the condition $7<R<9 \mathrm{~kg}$.

drawn in Figure 5c and d. The inverse value corresponds to a climatic mean-temperature gradient, $15^{\circ} \mathrm{Cm}^{-1}$.

\subsection{New criterion distinguishing the depth-hoar and dry-snow regions}

As discussed in section 3.1, the areas of the depth-hoar region derived here, which have the climatic mean temperature gradient approximately greater than $15^{\circ} \mathrm{Cm}^{-1}$, are slightly smaller on Hokkaido Island than those discussed by previous authors. Therefore, presumed regions of depth hoar on Hokkaido with a smaller critical climatic mean temperature gradients than $15^{\circ} \mathrm{C} \mathrm{m}^{-1}$ were examined (Fig. 7). Comparing Figure 7 with Figure 4, we find values of the climatic mean temperature gradient from $10^{\circ}$ to $12^{\circ} \mathrm{C} \mathrm{m}^{-1}$ appropriate to delimit the depth hoar from the dry-snow

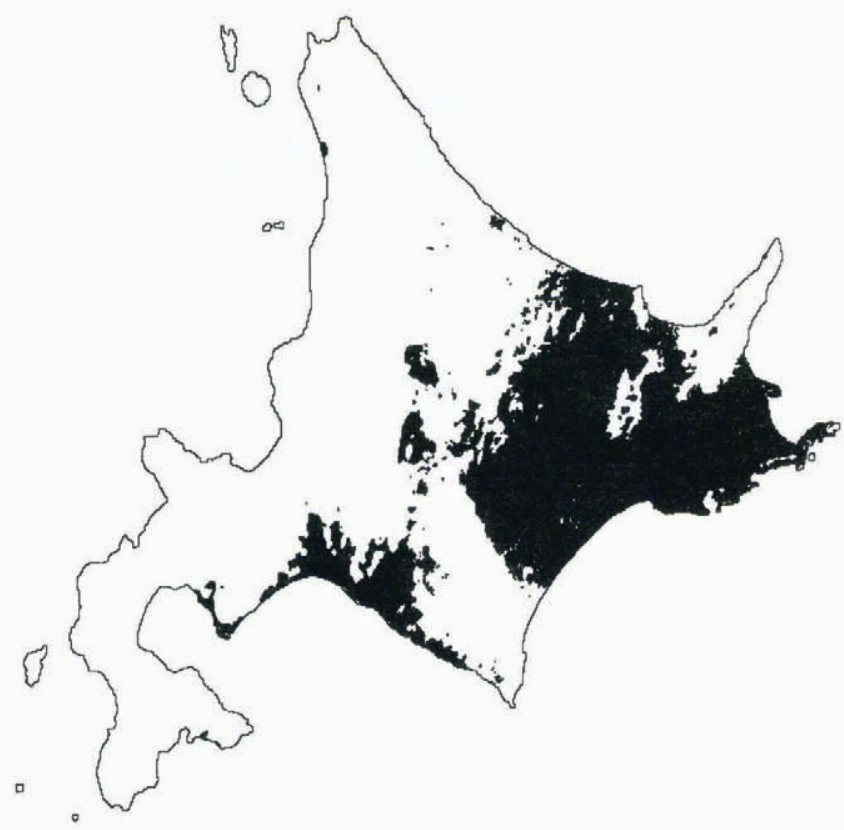

(a) $\frac{|\bar{T}|}{\overline{H S \max }}>12^{\circ} \mathrm{C} \mathrm{m}^{-1}$ region. The delimitation method, based on the climatic mean temperature gradient, gives more general criteria than those with the approximated rammsonde hardness calculated using Equation (1). Therefore, the description of the climatic conditions for the delimitation of the depth-hoar region in Table 2 can be improved, as is shown in Table 3 .

The climatic mean temperature gradient to indicate the development of depth hoar has been introduced by other authors. Akitaya and Endo (1977) proposed the "climatic" mean temperature gradient, by dividing the mean air temperature by the mean snow depth in January. Kawashima and others (1994) have also presented the "temperature-gradient index" for indicating the degree of temperature-gradient metamorphism. That is obtained by dividing the mean air temperature from the beginning of snow deposition to any day by the mean snow depth during the same period. Their indexes are well suited to explain the formation of depth hoar but are sensitive to the meteorological conditions each winter. The temperature gradient obtained here is a climatic one which characterizes the meteorological conditions averaged for a long time period. But, here the maximum snow depth of a 2 month period is used, thus the temperature gradient obtained is supposed to be smaller than that calculated using a mean snow depth.

\section{SUMMARY AND GONCLUDING REMARKS}

For the climatic division of snowy areas in Japan, four categories according to the snow-cover characteristics in midwinter were introduced and adopted. The results explain the time lag of wet-grain formation in different snow regions and also the distribution of depth-hoar areas on Hokkaido Island. Examining the relationships between the climatic mean air temperature and the maximum snow depth during January and February for each category, we

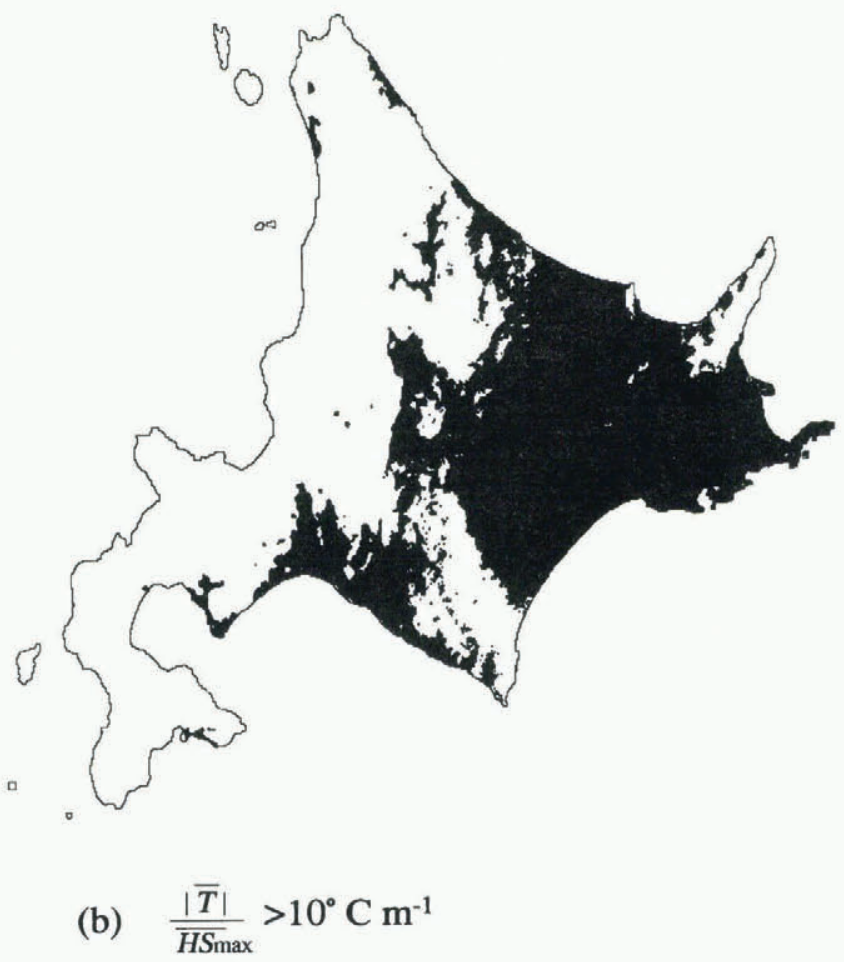

Fig. 7.The presumed depth-hoar regions with a smaller critical temperature gradient. In cases $(a)$ and $(b)$, the areas correspond to regions which have a climatic mean temperature gradient greater than $12^{\circ}$ and $10^{\circ} \mathrm{Cm}^{-1}$, respectively. https://doi.org/10.3189/1998AoG26-1-131-137 Published online by Cambridge University Press 
Table 3. Revised climatic conditons for the depth-hoar region

\begin{tabular}{lll}
\hline Category for division & Climatic conditions & Characteristics of snow cover \\
\hline Depth-hoar region & $T_{\mathrm{jan}}<-1.1^{\circ} \mathrm{C}$ & $\begin{array}{l}\text { Low temperature and small snow depth. The negative temperature gradient in } \\
\text { and }\end{array}$ \\
$|\bar{T}| / \overline{H S}_{\max }>10 \sim 12^{\circ} \mathrm{C} \mathrm{m}^{-1}$ & $\begin{array}{l}\text { The climatic mean temperature gradient }|\bar{T}| / \overline{H S}_{\max } \text { is derived by dividing } \\
\text { the climatic monthly mean air temperature by the climatic monthly maxi- } \\
\text { mum snow depth during January and February, }\end{array}$ \\
\hline
\end{tabular}

find that in the wet-snow region the upper limit of the snow depth decreased almost linearly with a mean air-temperature increase and that the criteria between the dry-snow and the depth-hoar regions is given by the form of a climatic mean-temperature gradient.

Here, the simple and general conditions for the climatic division of snow cover inJapan were obtained.The division developed here, together with the snow-cover quantities, could be of use in many fields such as defense against snow disasters, use of snow as a resource and for planning winteractivities, e.g. sporting events and entertainment. This division might also be related to the distribution of plants and other lives.

\section{ACKNOWLEDGEMENTS}

The author wishes to express his thanks to the Japanese Meteorological Agency for providing the climatic dataset. The author should also like to express his thanks to Prof. S. Kobayashi and Dr K. Izumi, Niigata University, for their helpfulsuggestions. This work was partly supported by a grant from the Ministry of Education, Science and Culture, Japan.

\section{REFERENCES}

Akitaya, E. and Y. Endo. 1977. [Regional characteristics of the snow cover in Ishikari and Sorachi District, Hokkaido.] Low Temp. Sci., Ser. A 35, 105115. [InJapanese with English summary.]

Akitaya, E. and Y. Endo. 1980. [Characteristics of the snow cover in midwinter in Hokkaido.] Low Temp. Sci., Ser. A 39, 55-61. [In Japanese with English summary.]

Akitaya, E. and Y. Endo. 1982. [Regional characteristics of snow cover in Hokkaido.] In Research Report Grant-in-Aid for special project of Hokkaido University, 1979 81]. Sapporo, Hokkaido University, 1-17. [InJapanese.]

Izumi, K. and E. Akitaya. 1986. [The distribution of depth hoar in Honshu, Japan.] Seppyo, 7. Jpn. Soc. Snow Ice, 48(4), 199-206. [In Japanese with English summary.]

Kawashima, K., T. Yamada and G. Wakahama. 1987. [Dividing of snow-depositional environments and characteristics of snow in the coastal region of the Japan Sea.] Low Temp. Sci., Ser. A 46, 1-13. [In Japanese with English summary.]

Kawashima, K., T. Yamada and G. Wakahama. 1994. Regional division of snow-depositional environments and metamorphism of snow cover in plain areas along the Japan Sea coast. International Association of Hydrological Sciences Publication 223 (Symposium at Yokohama 1993-Snow and Ice Covers: Interactions with the Atmosphere and Ecosystems), 187-196.

Nakamura, T. 1979. Local features of snow cover of Japan in January. Report of the National Research Center for Disaster Prevention 22, 175-177. 